\title{
Distribution of Flood Risk Area in Bodri Watershed of Kendal Regency
}

\author{
Husna Fauzia $^{1 *}$, Eka Cahyaningsih ${ }^{1}$, Hery Nugroho Hariyanto ${ }^{1}$, Satya Budi Nugraha ${ }^{2}$ \\ ${ }^{I}$ Department of Public Works of Water Resources and Spatial Planning of Central Java Province, Indonesia \\ ${ }^{2}$ Department of Geography, Faculty of Social Sciences, Universitas Negeri Semarang, Indonesia \\ Corresponding Author: husnafauzia@gmail.com
}

\begin{tabular}{llll} 
Article history & & & \\
\hline Received & Received in revised form & Accepted & Available online \\
22 June 2021 & 29 August 2021 & 04 September 2021 & 18 September 2021 \\
\hline
\end{tabular}

\begin{abstract}
Flooding is a catastrophic phenomenon that can occur due to various factors, such as uncontrolled landuse changes, climate change, and weather anomalies, and drainage infrastructure damage. The Bodri watershed in Kendal Regency is one of the watersheds in Central Java, which is categorized as critical based on Decree No. 328/Menhut-II/2009. Some of the problems in the Bodri watershed include land use that is not suitable for its designation, flooding, erosion, and landslides. This study aims to conduct spatial modeling to create flood hazard maps and flood risk level maps in the Bodri watershed. The method used is hydrograph analysis, flood modeling, potential flood hazards, and flood risk levels. Analysis of the potential for flood hazards from the spatial modeling inundation map with the input of the flood peak return period of 2 years (Q2), 5 years (Q5), and 50 years $(\mathrm{Q} 50)$. Vulnerability analysis based on land use maps of flood hazard areas. The distribution of flood-prone areas in the Bodri watershed is in Pidodo Kulon Village, Pidodo Wetan Village, and Bangunsari Village.
\end{abstract}

Keywords: Bodri Watershed, distribution, flooding, spatial planning.

\section{Introduction}

A Watershed is a natural system where the hydrological biophysics process and the community's socio-economic activities occur [1]. This process is part of the hydrological cycle or water cycle, which can lead to changes in the carrying capacity of a watershed. One of the factors that can affect the carrying capacity is humans with all their activities. Human activities could impact the watershed's hydrological conditions. Besides, leading to decreased land productivity, increased erosion and sedimentation, and accelerated land degradation. In addition, humans can have a role as agents of improvement towards the watershed ecosystem's deteriorating physical condition and function.

Based on the Presidential Decree on the designation of river basins [2], Central Java Province consists of 202 watersheds. One of the watersheds in Central Java that has been damaged and is included in critical watersheds is the Bodri watershed. The Ministry of Forestry identified critical watersheds in 2009 by including the Bodri Watershed as one of the 108 watersheds considered critical [3]. Bodri Watershed is one of the watersheds under the authority of the Central Java Province Government under the supervision of the Environment and Forestry Service of Central Java Province.

The Bodri watershed covers three districts, namely Temanggung Regency, Semarang Regency, and Kendal Regency. The upstream part of the Bodri watershed is in Temanggung Regency, while the downstream part is Kendal Regency (Figure 1). The Bodri watershed has a forest area of $\pm 16,504.12$ ha or $\pm 25.31 \%$ of the total area of the Bodri watershed [4]. It has not fulfilled the forest area requirement of at least $30 \%$ of the river flow area. Critical land in the Bodri watershed is scattered both in the upstream and downstream areas [5]. One of the ways to see this criticality is the widespread conversion of land functions that have occurred. The land-use change is a buffer area into a residential area and a cultivation area. One of the causes of land-use change in the Bodri watershed is an increase in the population and socio-economic activities of the local community [6]. The increase in population causes uncontrolled landuse change and causes adverse environmental effects [7][8]. 


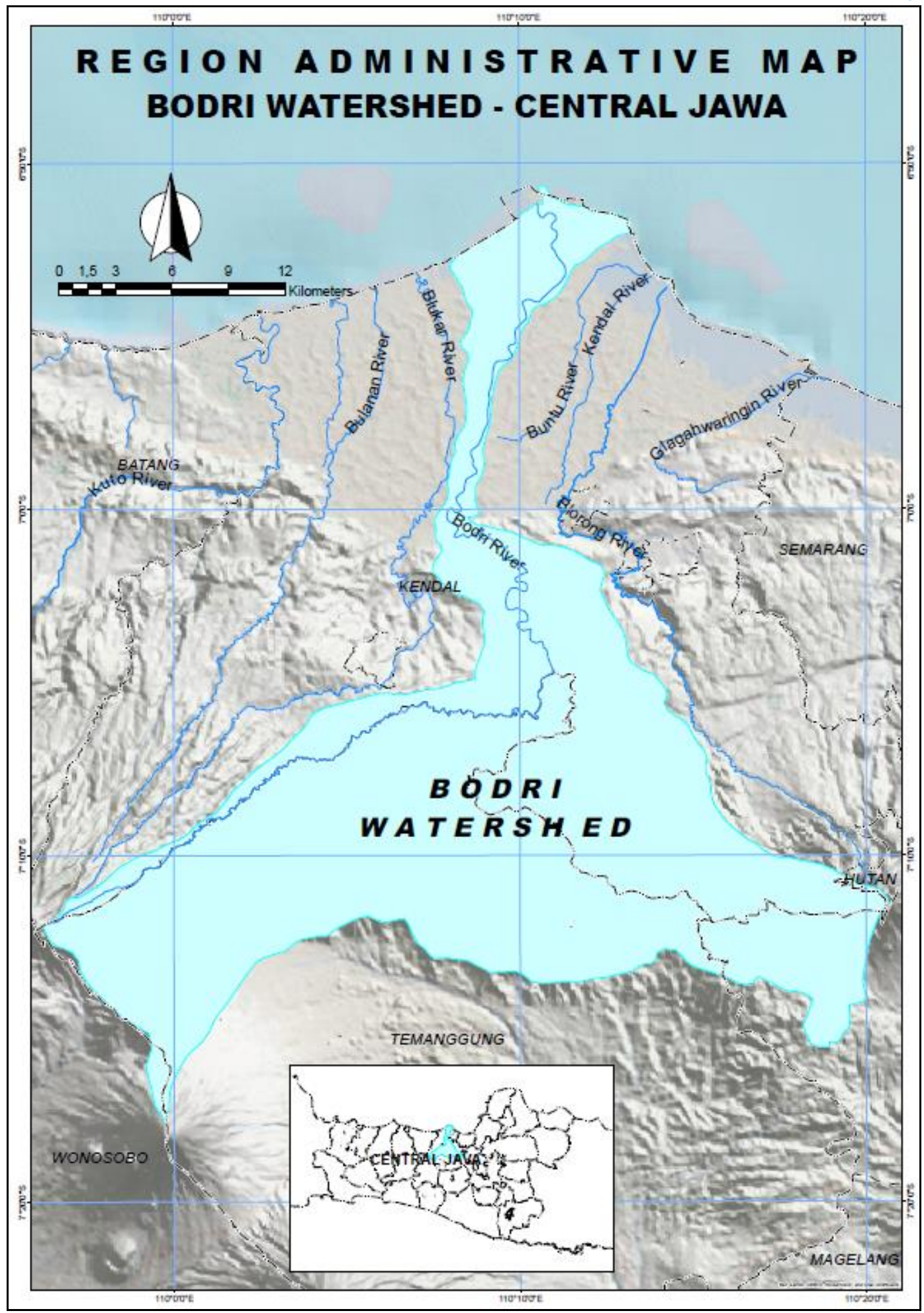

Figure 1. Administration Map of Bodri Watershed

(Source: base map of BIG, 2018)

Bodri watershed current conditions are deplorable. Bodri Basin area of critical land has 14033.51 ha or $21.52 \%$ of the total area, especially in the upstream watershed Bodri [9]. This condition is caused by agricultural activities that have not implemented soil conservation efforts in land management. The areas with the most critical level are in the upstream area of the Bodri watershed, based on the Decree of the Minister of Environment and Forestry concerning Designation of Critical Land No. SK. 306/MENLHK/PDASHL/DAS.0/7/2018, including Tretep, Wonoboyo, Gemawang, and Kandangan Districts at Temanggung Regency, also Singorojo District at Kendal Regency [6].

As a result of land use that does not pay attention to conservation principles, especially on land with a steep slope, triggers erosion. It results in sedimentation at the downstream Bodri watershed area. Erosion in the upstream part of the Bodri watershed has resulted in considerable sedimentation in the downstream Bodri watershed. It can be indicated by silting the river. Silting the river causes 
the river's capacity to decrease. It makes to be prone to flooding in Kendal Regency during the rainy season. In addition to flooding, especially in the downstream area of Kendal Regency every year, in the Bodri watershed area, there is also drought during the dry season. These conditions indicate that the Bodri watershed has decreased the quality of the environment and ecosystem [10].
The Bodri watershed flood disaster in Kendal Regency occurred in several places, including Singorojo District, Patebon District, and Cepiring District [11]. The details of flood events that occurred in the Bodri watershed, described in Table 1.

Table 1. Flood Events in Bodri Watershed

\begin{tabular}{|c|c|c|c|c|}
\hline No & Location & Flood Type & Event Record & Initial Cause Indication \\
\hline 1. & $\begin{array}{l}\text { Kartika Jaya Village } \\
\text { (Patebon District) }\end{array}$ & $\begin{array}{l}\text { Coastal } \\
\text { (tidal) flood }\end{array}$ & 1 December 2017 & Settlements that are often affected by rob and floods \\
\hline 2. & $\begin{array}{l}\text { Pidodo Kulon Village } \\
\text { (Patebon District) }\end{array}$ & $\begin{array}{l}\text { Coastal } \\
\text { (tidal) flood }\end{array}$ & 22 February 2018 & $\begin{array}{l}\text { Rob often occurs due to river runoff; need to raise the } \\
\text { embankment }\end{array}$ \\
\hline 3. & $\begin{array}{l}\text { Pidodo Kulon Village } \\
\text { (Patebon District) }\end{array}$ & $\begin{array}{c}\text { Coastal } \\
\text { (tidal) flood }\end{array}$ & 19 January 2019 & $\begin{array}{l}\text { Rob often occurs due to river runoff; need to raise the } \\
\text { embankment }\end{array}$ \\
\hline 4. & $\begin{array}{l}\text { Pidodo Kulon Village } \\
\text { (Patebon District) }\end{array}$ & $\begin{array}{c}\text { Coastal } \\
\text { (tidal) flood }\end{array}$ & 27 January 2019 & $\begin{array}{l}\text { Rob often occurs due to river runoff; need to raise the } \\
\text { embankment }\end{array}$ \\
\hline 5. & $\begin{array}{l}\text { Bangunsari Village } \\
\text { (Patebon District) }\end{array}$ & River flood & 22 February 2018 & $\begin{array}{c}\text { The retaining wall on the right side of the river is } \\
\text { damaged/collapsed }\end{array}$ \\
\hline 6. & $\begin{array}{l}\text { Wonosari Village } \\
\text { (Patebon District) }\end{array}$ & River flood & 21 February 2016 & $\begin{array}{l}\text { When the rain intensity is high, the river water often } \\
\text { overflows into the rice fields }\end{array}$ \\
\hline 7. & $\begin{array}{l}\text { Singorojo Village } \\
\text { (Singorojo District) }\end{array}$ & River flood & 23 April 2017 & $\begin{array}{l}\text { When the rain intensity is high, river water often } \\
\text { overflows onto roads and residential areas; Channels are } \\
\text { too small to receive runoff from upstream; some houses } \\
\text { block the sewers downstream of the channel }\end{array}$ \\
\hline 8. & $\begin{array}{l}\text { Singorojo Village } \\
\text { (Singorojo District) }\end{array}$ & River flood & 31 March 2020 & $\begin{array}{l}\text { When the rain intensity is high, river water often } \\
\text { overflows onto roads and residential areas; Channels are } \\
\text { too small to receive runoff from upstream; some houses } \\
\text { block the sewers downstream of the channel }\end{array}$ \\
\hline
\end{tabular}

The flood disaster caused significant losses to the government and the surrounding community. Efforts are needed to anticipate the occurrence of the Flood Disaster to reduce the impact of losses felt by the government and society. This study aims to perform spatial modeling to create flood hazard maps and flood risk level maps in the Bodri watershed. The map of the distribution of hazards, vulnerability, and risk of flooding can be considered in spatial planning. According to the existing spatial planning plan, efforts aim to reduce the risk of more severe flooding in the future.

The use of a Geographical Information System (GIS) in the mapping process, especially to create flood hazard maps, flood vulnerability maps, and flood risk maps, have been implemented at Dengkeng Watershed [12], at Bengawan Solo River [13], at Kendal and surrounding area [14], at Hurghada-Egypt [15], and Mert River, Turkey [16]. Making these maps can be identified quickly, easily, and accurately using the overlay method of the flood parameters used in this study with the help of a Geographical Information System, namely ArcGIS 10.3 software. It is used to facilitate the presentation of spatial information. Also, particularly to determine the flood risk level, analyze and obtain information related to identifying areas frequently subject to flooding.

\section{Material and Methods}

\subsection{Materials}

The data used in this research are geospatial and hydrological data, along with other supporting data. Geospatial data is geographic location, dimensions, size, and characteristics of natural or artificial objects below, on, or above the earth's surface. Geospatial information is the result of geospatial processing data [17].

This research's geospatial data/information consists of basic geospatial data/information (BGI) and thematic geospatial data/information (TGI). These data include:

1) TGI for the Bodri watershed (DAS) and its rivers;

2) BGI administrative area boundaries;

3) DEM National;

4) TGI land cover;

5) TGI inundation.

Meanwhile, the hydrological data required in this study consist of:

1) 10-year rainfall data

2) River discharge data

Other supporting data are flood events, flow coefficients, population, social and economic data. 


\subsection{Methods}

The method used is hydrological/hydraulic modeling and spatial modeling to analyze the flood risk level based on hazard level and vulnerability classification. Spatial modeling is a series of analytical procedures used to obtain information about the relationship between various geographical phenomena [18], [19].

\subsubsection{Sample collection and preparation}

The data collection method used in this study was primary and secondary data. Primary data is obtained from focused discussions with stakeholders from related agencies and information from the community. Secondary data is obtained from previous studies, books, research results, journals, and data from agencies that oversee them. The secondary data are from the Public Works Department of Water Resources and Spatial Planning of Central Java Province (PUSDATARU), Meteorology Climatology and Geophysics Council (BMKG) Semarang Station, and Regional Disaster Management Agency (BPBD) of Central Java Province.

\subsubsection{Experimental variable and analytical procedures}

Spatial modeling techniques carried out the analysis of the flood risk level in the Bodri watershed. The stages are carried out systematically in this study, namely:

1) Studying Literature;

2) Surveying and collecting data;

3) Processing of hydrological data;

4) Analyzing of flood discharge with a specific return period;

5) Conducting cross-sectional analysis of the river;

6) Creating a flood inundation map;

7) Creating a flood hazard map from an inundation map by taking its depth information;

8) Determining and creating flood vulnerability maps based on land cover maps;

9) Determining and creating a flood risk level map based on the level of danger and vulnerability.

\subsubsection{Data analysis}

The analytical method used to achieve the research objectives is a spatial analysis technique with an overlay analysis approach to producing a new map using scoring on each map input. Weighting is carried out on the existing parameters, namely the depth of flood and land cover, and given a value according to their respective classification. The variable that most influences flood risk level can be determined based on the impact obtained in the form of potential loss and damage to an area that can affect social and economic life.

While the hydrological analysis method to obtain a specific return period flood discharge in the Bodri watershed is used several methods, including the HSS Gama I Method, the Nakayasu Method, the
Weduwen Method, the Haspers Method, the Rational Method, and the HEC-HMS Modeling. After analyzing the method mentioned above, it will then be verified and calibrated with existing discharge data.

Hydrology analysis was carried out to determine the flood discharge design for a specific return period. It will create inundation maps in the Bodri watershed. The stages of activities in the hydrological analysis include 1) Analysis of the mean rainfall; 2) Analysis of the frequency of rainfall; 3) Calculation of planned rainfall; 4) Calculation of adequate hourly rainfall; 5) Analysis of design flood discharge; 6) Calibrate the design flood discharge with existing river discharge data.

The flood hazard map was made an overlay analysis approach between the flood inundation maps (Q5 and Q50) and the national data digital elevation model (DEM). The level of inundation data was extracted from DEM. The highest elevation data is assumed to be the inundation boundary. Then, data can be obtained from the height or flood depth of each location from the inundation limit.

To determine the flood hazard level in the Bodri watershed, scoring the flood depth is carried out with the classification of flood hazard classes as outlined in Table 2.

Table 2. Flood Hazard Classification of Bodri Watershed

\begin{tabular}{ccc}
\hline Inundation Depth $(\mathrm{m})$ & Hazard Level & Score \\
\hline Not flooded & No hazard & 0 \\
$>0.0-1.5$ & Low hazard & 1 \\
$>1.5-3.0$ & Medium hazard & 2 \\
$>3.0-4.5$ & High hazard & 3 \\
$>4.5-6.0$ & Very high hazard & 4 \\
\hline
\end{tabular}

(Source : Modified from Woods [20])

The scoring of the flood hazard classification is based on the depth of flood inundation. It can be said that the higher an area is inundated, the higher the level of danger in that area.

The level of flood vulnerability is based on the classification of land use in inundated areas. Land use is a volatile parameter due to the influence of human intervention. Land use is an essential factor affecting the level of flood vulnerability in an area.

Determining the level of vulnerability is carried out using a scoring approach. Parameters considered to have potential severe damage and losses are given a high score. Conversely, the lower the potential damage and losses, the lower the score will be. Scoring and classification of flood vulnerability can be seen in Table 3 . 
Table 3. Flood Vulnerability Classification of Bodri Watershed

\begin{tabular}{ccc}
\hline Land Cover Type & $\begin{array}{c}\text { Vulnerability } \\
\text { Classification }\end{array}$ & Score \\
\hline Forest & Not vulnerable & 0 \\
Shrubs & Less vulnerable & 1 \\
Field/garden & Medium vulnerable & 2 \\
Rice field/pond & Vulnerable & 3 \\
Settlement & Very vulnerable & 4 \\
\hline
\end{tabular}

(Source: Modified from Darmawan and Theml [21])
Flood characteristic data used in flood risk mapping are flood hazard levels and flood vulnerability levels. In order to determine the flood risk level, scoring is carried out based on the multiplication of the flood hazard value and the flood vulnerability value. The higher the multiplication result, the higher the risk of flooding and vice versa. The results of the flood risk classification are presented in Table 4.

Table 4. Flood Risk Classification of Bodri Watershed

\begin{tabular}{|c|c|c|c|c|c|c|}
\hline $\begin{array}{c}\text { Risk Value } \\
\text { Hazard Level }\end{array}$ & $\begin{array}{c}\text { Vulnerability } \\
\text { Classification } \\
\text { Score } \\
\end{array}$ & $\begin{array}{c}\text { Very } \\
\text { Vulnerable } \\
4 \\
\end{array}$ & $\begin{array}{c}\text { Vulnerable } \\
3\end{array}$ & $\begin{array}{c}\text { Medium } \\
\text { Vulnerable } \\
2 \\
\end{array}$ & $\begin{array}{c}\text { Less } \\
\text { Vulnerable } \\
1 \\
\end{array}$ & $\begin{array}{c}\text { Not Vulnerable } \\
0 \\
\end{array}$ \\
\hline Very high hazard & 4 & 16 & 12 & 8 & 4 & 0 \\
\hline High hazard & 3 & 12 & 9 & 6 & 3 & 0 \\
\hline Medium hazard & 2 & 8 & 6 & 4 & 2 & 0 \\
\hline Low hazard & 1 & 4 & 3 & 2 & 1 & 0 \\
\hline No hazard & 0 & 0 & 0 & 0 & 0 & 0 \\
\hline
\end{tabular}

(Source: modified from Cahyono et al. [13])

\section{Results and Discussion}

\subsection{Hydrological Analysis}

The rainfall data used to analyze the mean rainfall in the Bodri watershed area used daily data for the last ten years (2010 - 2019) from rain observation stations scattered around them, namely Tempuran, Patean Curug, and Klepu Wd Station. Rainfall data obtained from the rain station occurs in one place or point (point rainfall), so an analysis of regional rainfall is needed. This study is analysis of the regional average rainfall uses the Thiessen Polygon method with detailed results in Table 5.

Table 5. Maximum Rainfall of Bodri Watershed

\begin{tabular}{ccc}
\hline No & Year & Max Rainfall $(\mathrm{mm})$ \\
\hline 1 & 2010 & 134.98 \\
2 & 2011 & 96.94 \\
3 & 2012 & 140.89 \\
4 & 2013 & 69.41 \\
5 & 2014 & 159.60 \\
6 & 2015 & 40.81 \\
7 & 2016 & 72.05 \\
8 & 2017 & 114.44 \\
9 & 2018 & 75.49 \\
10 & 2019 & 111.47 \\
\hline
\end{tabular}

Design rainfall is the most significant annual rainfall with a certain probability of occurring in an area. In calculating the design rainfall, a frequency analysis of the existing rainfall data was carried out to find the relationship between the magnitude of extreme events and the frequency of occurrences using a probability distribution. The choice of method was adjusted to the statistical parameters, namely Cs (skewness) and $\mathrm{Ck}$ (kurtosis). The results of the design rainfall calculation in the Bodri watershed are presented in Table 6.

The rainfall distribution results use the Normal distribution method, Log-Normal, Gumbel, and Log Pearson III. It was then tested with the SmirnovKolmogorov Test and Chi-Square Test to analyze the suitability of the data between the observed frequency and the expected frequency. Based on the test results, the planned rainfall used for the planned flood discharge analysis is the Log-Normal distribution. The method is used because the maximum delta that occurs is 000,000 . The chi-square value that occurs is 000,001 , which is smaller than the critical chi value 000,006 .

From the calculation results of the planned rainfall with various return periods, the planned flood discharge is obtained with several empirical methods, including Rational, Haspers, GAMMA 1, Weduwen, Nakayasu, and HEC-HMS.

The main objective of the flood discharge analysis is to obtain the peak discharge of the Bodri watershed with a return period of 2 years (Q2), 5 years (Q5), 10 years (Q10), 25 years (Q25), 50 years (Q50) and 100 years $(\mathrm{Q} 100)$. The results of the design flood discharge calculations in the Bodri watershed can be seen in Table 7. 
Table 6. Rainfall Calculation Design of Bodri Watershed

\begin{tabular}{cccccccccc}
\hline \multirow{2}{*}{$\begin{array}{c}\text { Probability In } \\
\text { Order }\end{array}$} & \multirow{2}{*}{ Time } & \multicolumn{4}{c}{ Rainfall Characteristics (mm) According to the Probability } \\
\cline { 3 - 10 } & $\mathrm{T}$ (year) & \multicolumn{2}{c}{ Normal } & \multicolumn{3}{c}{ Log-Normal } & \multicolumn{2}{c}{ Gumbel } & \multicolumn{2}{c}{ Log Pearson III } \\
$\mathrm{P}(\mathrm{x}>=\mathrm{X})$ & & $\mathrm{K}_{\mathrm{T}}$ & $\mathrm{X}_{\mathrm{T}}$ & $\mathrm{K}_{\mathrm{T}}$ & $\mathrm{X}_{\mathrm{T}}$ & $\mathrm{K}_{\mathrm{T}}$ & $\mathrm{X}_{\mathrm{T}}$ & $\mathrm{K}_{\mathrm{T}}$ & $\mathrm{X}_{\mathrm{T}}$ \\
\hline $99.00 \%$ & 1.010 & -2.326 & 14.464 & -1.747 & 36.062 & -1.641 & 40.001 & -2.862 & 28.901 \\
$50.00 \%$ & 2.000 & 0.000 & 101.21 & -0.184 & 94.260 & -0.164 & 95.002 & 0.123 & 99.171 \\
$20.00 \%$ & 5.000 & 0.842 & 132.472 & 0.868 & 133.441 & 0.719 & 127.922 & 0.855 & 134.154 \\
$10.00 \%$ & 10.000 & 1.282 & 148.860 & 1.581 & 160.030 & 1.305 & 149.717 & 1.174 & 153.065 \\
$4.00 \%$ & 25.000 & 1.751 & 166.336 & 2.500 & 194.245 & 2.044 & 177.256 & 1.470 & 173.016 \\
$2.00 \%$ & 50.000 & 2.054 & 177.625 & 3.195 & 220.146 & 2.592 & 197.686 & 1.640 & 185.527 \\
$1.00 \%$ & 100.000 & 2.326 & 187.779 & 3.900 & 246.381 & 3.137 & 217.965 & 1.777 & 196.390 \\
\hline
\end{tabular}

Table 7. Analysis of Flood Discharge Design of the Bodri Watershed

\begin{tabular}{cccccccc}
\hline \multirow{2}{*}{ No. } & \multirow{2}{*}{ Time (year) } & Rational & Haspers & GAMMA 1 & Weduwen & Nakayasu & HMS \\
\hline 1 & & Q2 & 511.81 & 125.09 & 620.98 & 123.14 & 860.79 \\
2 & Q5 & 724.56 & 117.08 & 861.48 & 187.96 & 1204.83 & 767.30 \\
3 & Q10 & 868.93 & 212.37 & 1026.53 & 235.23 & 1438.29 & 897.70 \\
4 & Q 25 & 1054.71 & 257.77 & 1238.92 & 300.18 & 1738.72 & 1840.40 \\
5 & Q50 & 1195.34 & 292.15 & 1399.70 & 352.16 & 1966.14 & 2442.00 \\
6 & Q100 & 1337.80 & 326.96 & 1569.67 & 407.15 & 2196.50 & 3140.10 \\
\hline
\end{tabular}

The flood discharge calculation of Bodri watershed design uses several methods, namely Rational, Haspers, Gamma 1, Weduwen, Nakayatsu, and HEC-HMS. It is necessary to calibrate and verify using existing river discharge recording data to see that the flood discharge is closest to actual conditions in the field.
The Bodri River has a discharge recording station, namely the Juwero Automatic Water Level Recorder (AWLR) located near the Juwero Dam with coordinates $6^{\circ} 58^{\prime} 00$ "LS and 11008'00" East Longitude. From the HEC HMS modeling, it is known that the Juwero AWLR is near Junction 4 Bodri, so that discharge calibration is carried out at the outlet of Junction 4 Bodri (Figure 2 and 3).

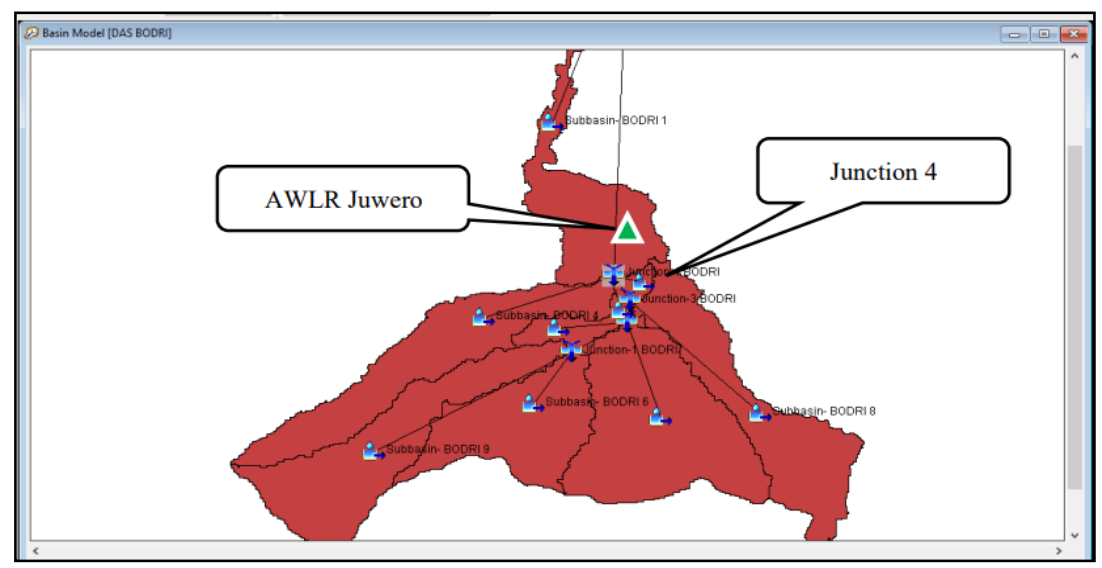

Figure 2. The Location of AWLR Juwero

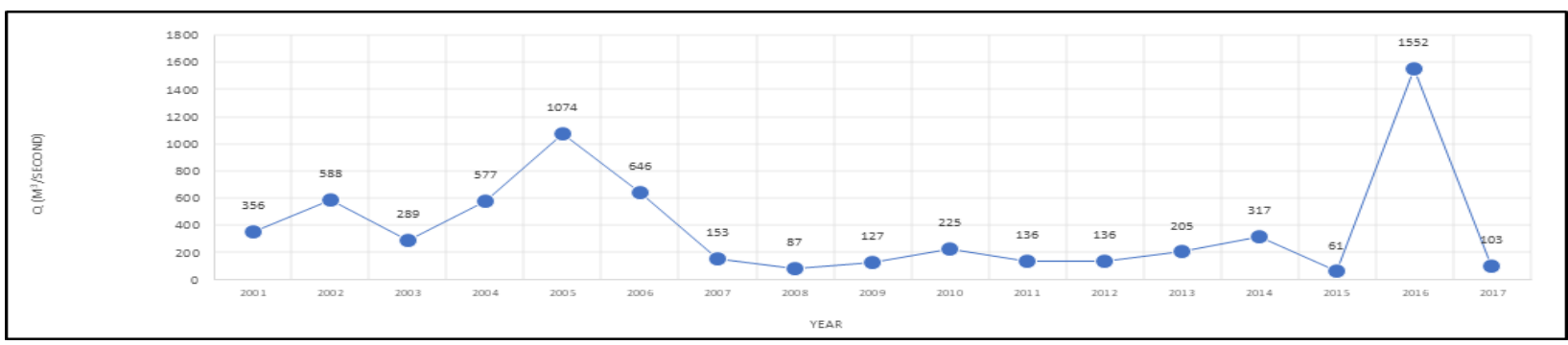

Figure 3. Debit Data Chart of AWLR Juwero 
The Juwero AWLR discharge data is then calculated using the Log-Normal Method to know the design flood discharge. The calibration results between the Bodri watershed design flood discharge at Junction 4 and the Juwero AWLR design flood discharge can be seen in Table 8 .

\subsection{Hydraulics Analysis}

Based on the results of the calibration calculations with the HEC-HMS method on the discharge data in the Juwero AWLR, the calculation of the flood discharge design for the Bodri watershed using the HEC-HMS model is closer to the available debit recording data so that in the following analysis the design discharge used is the result of the HECHMS modeling. The return period used were 2 years (Q2), 5 years $(\mathrm{Q} 5)$, and 50 years $(\mathrm{Q} 50)$.

Table 8. Calculation of the Bodri Watershed Flood Discharge Calibration

\begin{tabular}{ccccc}
\hline \multirow{2}{*}{ No } & \multirow{2}{*}{ Repeat Time (Year) } & \multicolumn{2}{c}{$\mathrm{Q}\left(\mathrm{m}^{3} / \mathrm{second}\right)$} & \multirow{2}{*}{ \% Error } \\
& & 231.80 & 263.12 & $12 \%$ \\
1 & 2 & 572.60 & 580.74 & $1 \%$ \\
2 & 5 & 897.70 & 878.43 & $2 \%$ \\
3 & 10 & 1393.50 & 1365.71 & $2 \%$ \\
4 & 25 & 1825.40 & 1816.22 & $1 \%$ \\
5 & 50 & 2364.00 & 2347.11 & $1 \%$ \\
6 & 100 & & \\
\hline
\end{tabular}

The hydraulic analysis aims to determine the ability of the river cross-section to accommodate the design flood discharge. In this study, the hydraulic analysis used the HEC-RAS 5.0 modeling to identify the flood inundation in the Bodri watershed and its area.

The data required in the hydraulic analysis with HEC-RAS modeling are the longitudinal and transverse sections of the river, the design flood discharge data, and the manning coefficient of the river cross-section. In the Bodri watershed, running HEC RAS 5.0 is carried out to see flood inundation by entering the flood discharge data input Q5 and Q50. Flood discharge Q5 is used to analyze the priority scale of handling, and Q50 is used for handling design parameters. The flood discharge used is the flood discharge with the HEC HMS method Q5 $=767.50 \mathrm{m3} / \mathrm{second}$ and Q50 $=2442.00 \mathrm{m3} / \mathrm{second}$.

Hydraulic analysis of floods in the Bodri watershed is used for mapping. It is then used to create flood hazard and vulnerability maps based on the land cover experiencing flooding. The hydraulic analysis of the Bodri watershed using the HEC-RAS modeling can be seen in Figures 4 and 5.

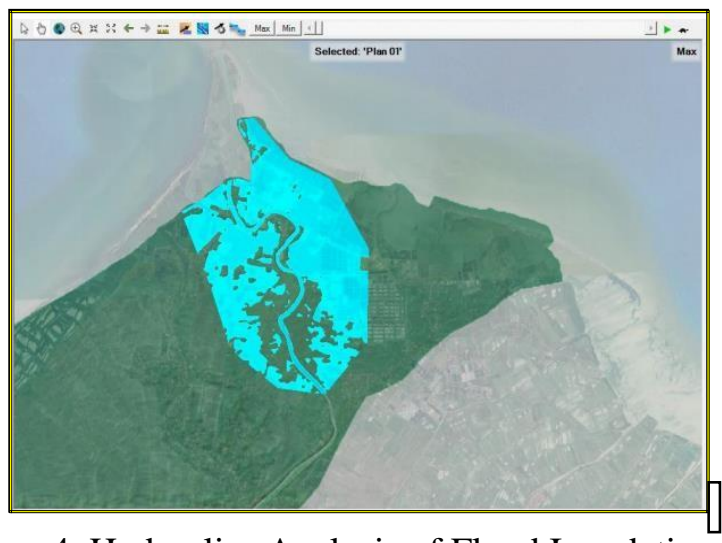

Figure 4. Hydraulics Analysis of Flood Inundation Q5

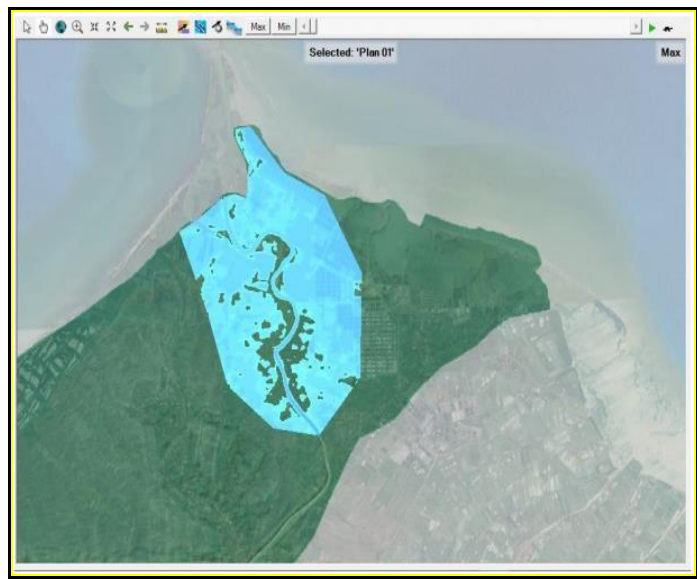

Figure 5. Hydraulics Analysis of Flood Inundation Q50 
Table 9. Inundation Matrix of Bodri Watershed

\begin{tabular}{|c|c|c|c|}
\hline \multirow{2}{*}{ Flood Discharge } & \multicolumn{2}{|c|}{ Inundated Location } & \multirow{2}{*}{ Inundation Area (ha) } \\
\hline & Village/ Subdristrict & District & \\
\hline \multirow{3}{*}{ Q5 } & Pidodo Kulon & Patebon & 126.11 \\
\hline & Pidodo Wetan & Patebon & 240.84 \\
\hline & Bangunsari & Patebon & 13.43 \\
\hline \multirow{3}{*}{ Q50 } & Pidodo Kulon & Patebon & 190.58 \\
\hline & Pidodo Wetan & Patebon & 421.92 \\
\hline & Bangunsari & Patebon & 16.36 \\
\hline
\end{tabular}

Based on the results of the HEC-RAS analysis, it can be seen that the inundated area in the Bodri River Basin is downstream, precisely in Patebon District. With the flood discharge design Q5, the total area of flood inundation that occurs is 380.38 ha or $0.62 \%$ of the total area of the Bodri Watershed. Meanwhile, with the flood discharge design Q50, the total flood inundation area that occurs is 628.86 ha or $1.03 \%$ of the Bodri Watershed (Table 9).

The greater the design flood discharge used, the wider the resulting inundation. The increase in the design flood discharge, which is influenced by rainfall, the catchment area, and the length of the main river, causes an increase in flood inundation in the Bodri watershed.

\subsection{Flood Hazard Map}

The modeling of the flood hazard map for the Bodri watershed is based on inundation depth with the design flood discharge used in Q5 and Q50. Flood discharge Q5 is used to analyze the priority scale of handling, and Q50 is used for handling design parameters.
Flood inundation that occurred downstream of the Bodri watershed has a depth of up to $4.5-5 \mathrm{~m}$ for Q5 flood discharge and 5.5 - $6 \mathrm{~m}$ for Q50 flood discharge. Flood inundation occurs because the downstream area of the Bodri watershed has a sloping topography. Even in certain parts of the river, the slope is almost close to 0 (zero). In addition, the downstream river has a meandering pattern that can inhibit the speed of water from being sent to the sea.

From the flood hazard map modeling, one map with the most significant discharge and inundation area was chosen to be used as the basis for preparing the flood vulnerability map of the Bodri watershed, namely the Flood Hazard Map Q50 (Figures 6 and 7).

Based on the flood hazard mapping Q50, it can be seen that at the low hazard level, the area is 6.35 ha, the medium hazard level is $94.47 \mathrm{ha}$, the high hazard level is 256.16 ha. In comparison, the very high hazard level is 246.90 ha.

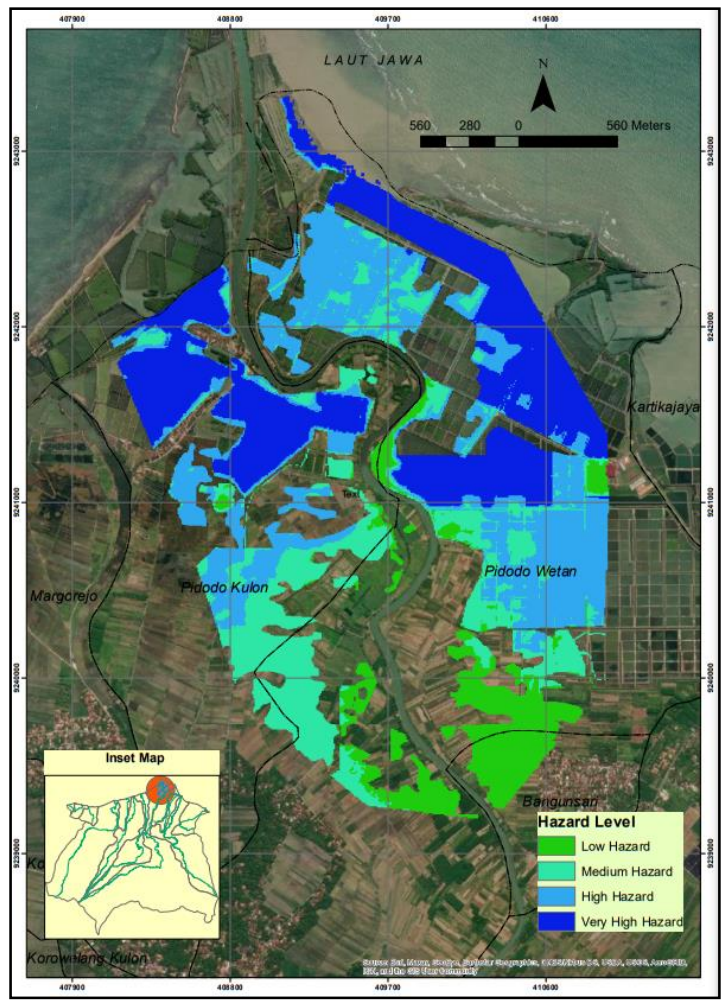

Figure 6. Flood Hazard Map of Q5 


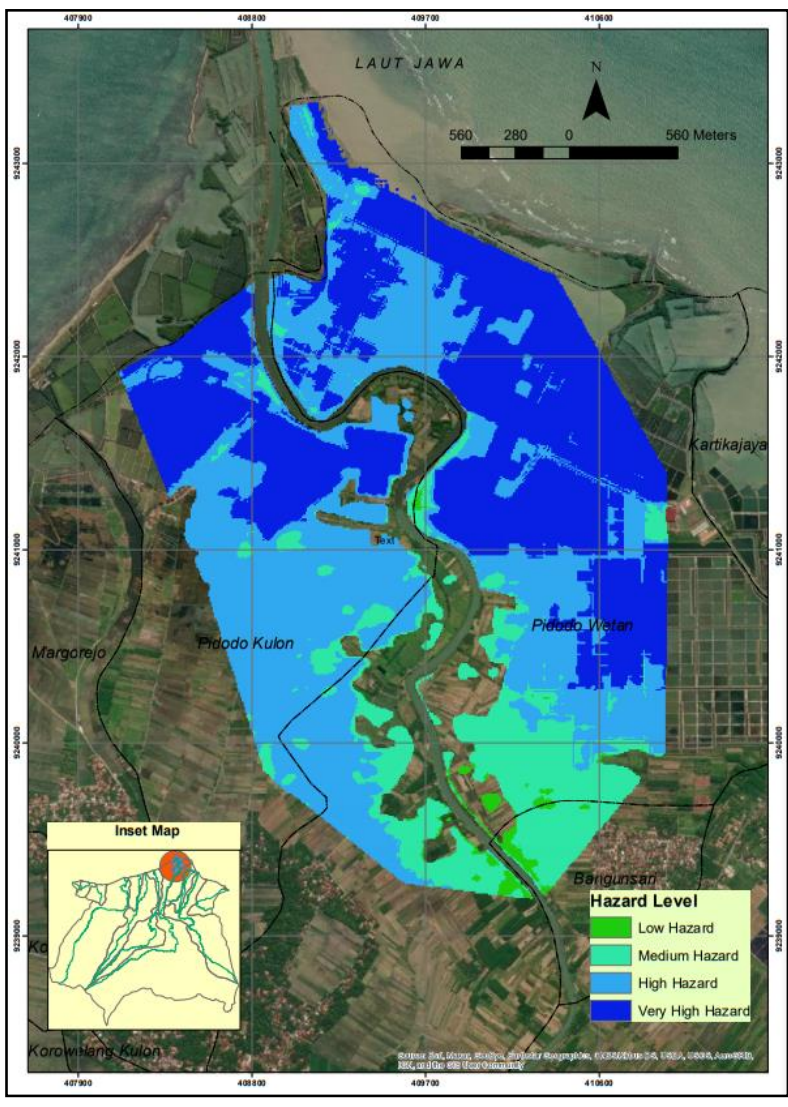

Figure 7. Flood Hazard Map of Q50

\subsection{Flood Vulnerability Map}

The level of flood vulnerability is based on the classification of land use in inundated areas. Preparation of flood vulnerability map results from inundation maps overlaid with a map of the land use classification, and scoring has been done before. Most of the flooded areas in the Bodri watershed are pond areas, so it can be seen that most of the areas are categorized as vulnerable. The flood vulnerability map of the Bodri watershed can be seen in Figure 8.

Areas categorized as very vulnerable are residential areas that are flooded. In contrast, the vulnerable category areas primarily found in the lower Bodri watershed are pond areas that are flooded (Figure 8). This condition is vulnerable because the inundation of settlements and ponds can cause lives, infrastructure, and economic activities loss.

Based on the flood vulnerability map, it can be seen that the area of the less vulnerable category is 8.51 ha, medium vulnerable is 0.06 ha, vulnerable is 588.29 ha. Meanwhile, the very vulnerable category is 6.74 ha.

\subsection{Flood Risk Map}

The flood risk level map is an overlay between the flood hazard map and the vulnerability map. The

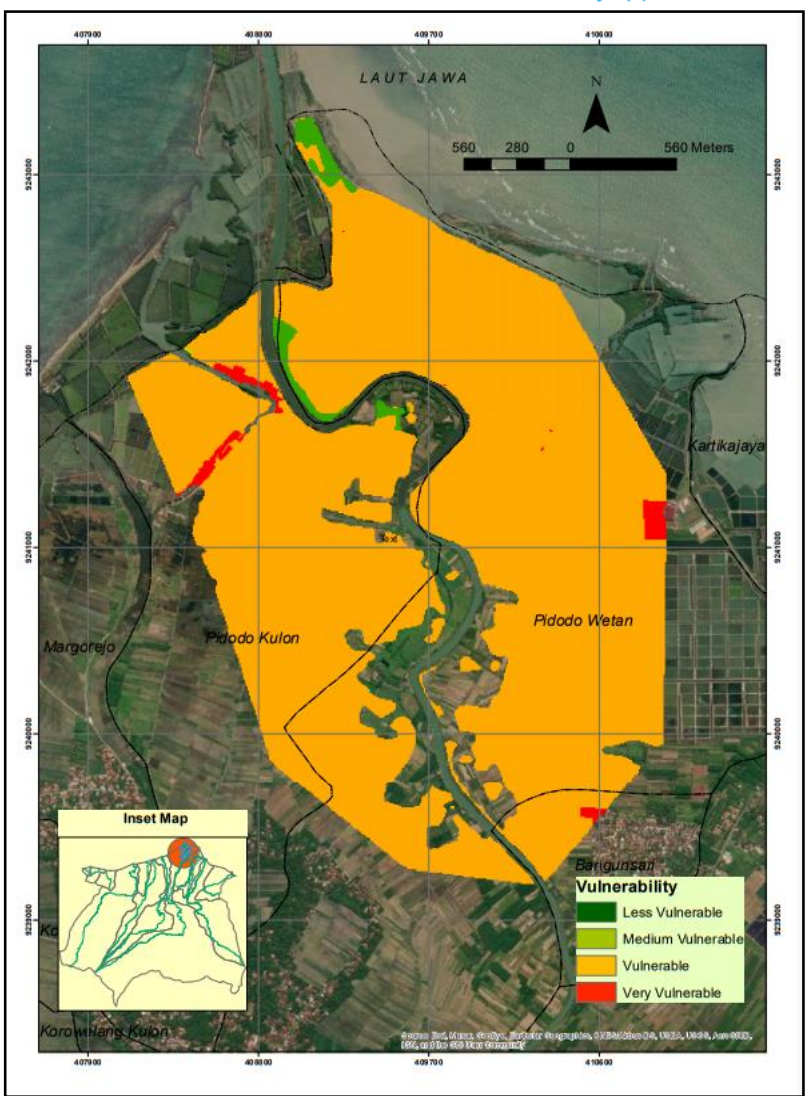

Figure 8. Flood Vulnerability Map of Bodri Watershed

results obtained are a map of the flood risk level in the Bodri watershed, grouped into four classes:

Very High Risk, High Risk, Medium Risk, and Low Risk. The Flood Risk Map of the Bodri Watershed is presented in Figure 9.

Based on the flood risk map, it can be seen that the area with the low-risk category includes an area of 13.55 ha. The medium-risk category covers an area of $91.88 \mathrm{ha}$. At the same time, the high-risk category covers an area of 250.57 ha. Meanwhile, 247.59 ha include in a very high-risk area.

Based on the spatial analysis results, it is known that the level of flood risk in the Bodri watershed is directly proportional to the level of danger or height of inundation. Areas with high and very high risk are ponds and settlements (a small part).

Land use affects the level of flood vulnerability in an area and contributes to the increase in flood discharge. The more open land coupled with high rainfall intensity, the more flood discharge will increase, which causes widespread flood inundation in a watershed. Widespread flood inundation will cause an increase in flood depth so that the level of danger and flood vulnerability will also increase. With the increase in the level of danger and flood vulnerability, the risk of flooding will also increase. 


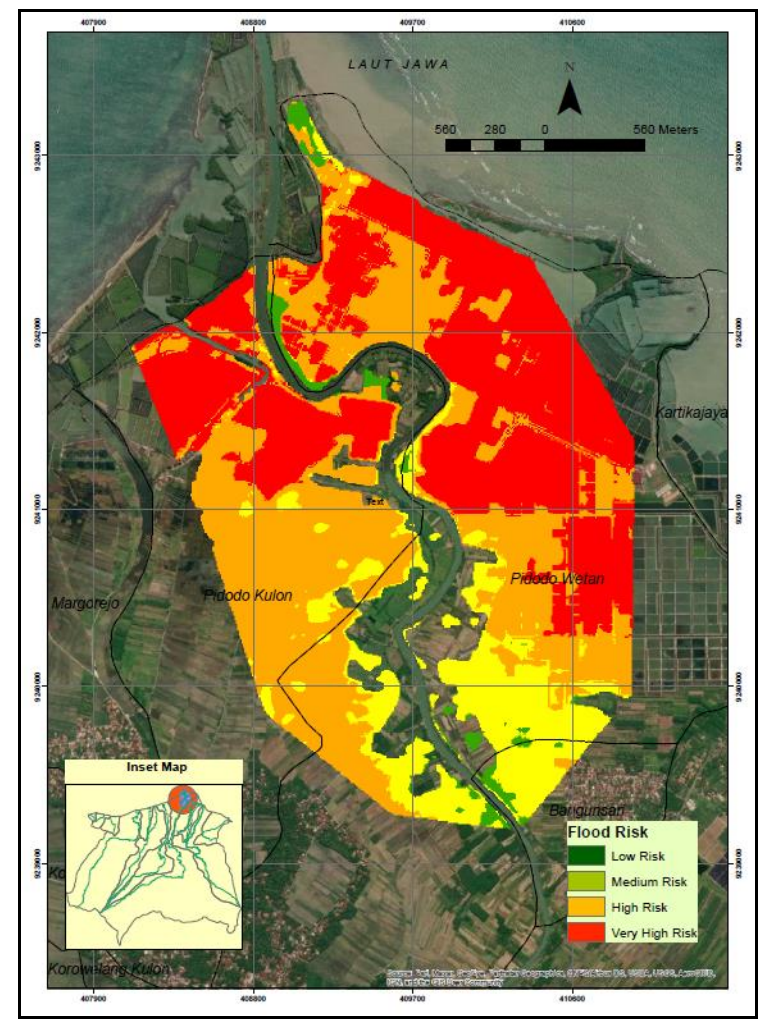

Figure 9. Flood Risk Map

\subsection{Spatial Planning Interventions for Flood Risk Reduction}

Spatial planning has a vital role in supporting efforts to protect areas from disaster risk. Collaboration between stakeholders in the region also needs to be increased to strengthen disaster risk management resources, especially those related to flood disasters [22]. The Kendal Regency Government has compiled a spatial plan that includes efforts to organize flood-prone areas. In addition to building a flood control system in Kendal Regency, especially in the Bodri Watershed through the construction of the Bodri Reservoir in Singorojo District, Kendal Regency Government has also prepared various policy programs for controlling spatial use as stated in the Kendal Regency Regional Spatial Planning (RTRW) 2011-2031 [23]. Among them, through the development of residential areas on land that is suitable for its designation and physically also supports it, including slope, availability, and quality of clean water sources, free from potential flooding/inundation and free from disasters,

In addition, the Kendal Regency Government carries out control and preservation of protected areas by implementing the following strategies:

1. Maintaining and restoring the function of protected forest;

2. Maintaining water catchment areas;

3. Limiting the development of cultivation activities in protected areas;

4. Avoiding high disaster-prone areas as built-up areas; and
5. Increase the area of urban green open space at a minimum level of $30 \%$.

The commitment and seriousness of the Kendal Regency Government to minimize the risk of flooding in Kendal Regency are also shown through several programs. Includes restoring the function of protected forests, rehabilitation, and restoration of natural resource reserves, developing tall standing vegetation that can protect the ground surface and absorb water into the forest. These programs are medium-term development targets planned by the Kendal Regency Government in the 2017-2021 period.

\section{Conclusion}

Based on spatial analysis and modeling results, the distribution of high-risk areas of flood located in Pidodo Kulon Village, Pidodo Wetan Village, and Bangunsari Village of Patebon District. The analysis results prove the recording of flood events already existed, especially in Pidodo Kulon and Bangunsari Village. Based on the flood risk map, it can be seen that the area with the low-risk category is 13.55 ha. The medium-risk category is $91.88 \mathrm{ha}$, and the highrisk category is $250.57 \mathrm{ha}$. At the same time, 247.59 ha include in a very high-risk area. The flood risk level in the Bodri watershed is directly proportional to the level of danger or height of inundation. The use of ponds and settlements dominates areas that are at high and very high risk of flooding.

Currently, the Kendal Regency Government has a program for developing a flood control system in the Bodri watershed upstream with the construction of the Bodri Reservoir. However, the success of this program cannot be determined because it has not been finished. In addition, technical controls and policies/regulations are needed to control land-use changes in upstream areas. Meanwhile, the downstream area of the Bodri watershed has a high and very high level of flood risk. The condition becomes worst because of other factors that could trigger floodings, such as tides and human activities. Therefore, in addition to planning technical programs, the Kendal Regency Government also needs to prepare non-technical programs, such as strengthening the capacity of the community and other stakeholders to deal with floods.

\section{Acknowledgment}

The author would like to thank the Department of Public Works of Water Resources and Spatial Planning of Central Java Province and the Regional Government of Kendal Regency for supporting this research. 


\section{References}

[1] Direktorat Jenderal Rehabilitasi Lahan dan Perhutanan Sosial, Pedoman Monitoring dan Evaluasi DAS. Indonesia, 2009.

[2] Keputusan Presiden Republik Indonesia, Penetapan Wilayah Sungai. 2012.

[3] Surat Keputusan Menteri Kehutanan Republik Indonesia, Penetapan DAS Prioritas Dalam Rangka RPJM 2010-2014. 2009.

[4] BPDAS Pemali Jratun, "Laporan Akhir Monitoring dan Evaluasi Pengelolaan DAS Bodri," Semarang, 2016.

[5] Dinas PU Sumberdaya Air dan Penataan Ruang Provinsi Jawa Tengah, "Studi Pengendalian Pemanfaatan Ruang pada Kawasan Khusus Provinsi Jawa Tengah,” Semarang, 2017.

[6] H. Fauzia, R. Setiadi, and S. B. Nugraha, "An analysis of Bodri watershed governance system," in E3S Web of Conferences ICENIS, 2019, vol. 125, pp. 1-5, doi: 10.1051/e3sconf/201912502004.

[7] S. Kundu, D. Khare, and A. Mondal, "Landuse change impact on sub-watersheds prioritization by analytical hierarchy process (AHP)," Ecol. Inform., vol. 42, pp. 100-113, 2017, doi: https://doi.org/10.1016/j.ecoinf.2017.10.007.

[8] X. Zhang, W. Cao, Q. Guo, and S. Wu, "Effects of land-use change on surface runoff and sediment yield at different watershed scales on the Loess Plateau," Int. J. Sediment Res., vol. 25, no. 3, pp. 283-293, 2010, doi: https://doi.org/10.1016/S10016279(10)60045-5.

[9] BPDAS Pemali Jratun, "Rencana Pengelolaan DAS Bodri," Semarang, 2015.

[10] I. Sriyana, "Evaluation of watershed carrying capacity for watershed management (a case study on Bodri watershed, Central Java, Indonesia)," in MATEC Web of Conferences ICRMCE, 2018, vol. 195, pp. 1-10, doi: 10.1051/matecconf/201819505003.

[11] H. Sailendra. "Kali Bodri dan Blorong Limpas, Beberapa Desa di Kabupaten Kendal Terendam Banjir"halosemarang.id.https://halosemarang.id /kali-bodri-dan-blorong-limpas-beberapa-desadi-kabupaten-kendal-terendam-banjir (accessed May 17, 2021).

[12] M. D. Aji N., B. Sudarsono, and B. Sasmito, "Identifikasi zona rawan banjir menggunakan sistem informasi geografis (Studi kasus: Sub
Das Dengkeng)," J. Geod. Undip, vol. 3, no. 1, p. 80286, 2014.

[13] T. Cahyono, M. P. Hadi, and D. Mardiatno, "Pemodelan spasial untuk pembuatan peta rawan banjir dan peta tingkat risiko banjir Bengawan Solo di Kota Surakarta," Maj. Geogr. Indones., vol. 29, no. 1, pp. 60-72, 2015.

[14] J. Matondang, S. Kahar, and B. Sasmito, "Analisis zonasi daerah rentan banjir dengan pemanfaatan sistem informasi geografis (Studi kasus : Kota Kendal dan Sekitarnya)," J. Geod. Undip, vol. 2, no. 2, pp. 103-113, 2013.

[15] K. I. Abdrabo et al., "Integrated methodology for urban flood risk mapping at the microscale in ungauged regions: A case study of Hurghada, Egypt," Remote Sens., vol. 12, no. 21, pp. 1-22, 2020, doi: 10.3390/rs12213548.

[16] V. Demir and O. Kisi, "Flood hazard mapping by using geographic information system and hydraulic model: Mert River, Samsun, Turkey," Adv. Meteorol., vol. Article ID, pp. 1-9, 2016, doi:10.1155/2016/4891015.

[17] Pemerintah Republik Indonesia, UndangUndang tentang Informasi Geospasial. 2011.

[18] H. R. Pourghasemi and C. Gokceoglu, Spatial modeling in GIS and $R$ for earth and environmental sciences. Elsevier, 2019.

[19] H. R. Moradi, M. T. Avand, and S. Janizadeh, Spatial Modeling in GIS and R for Earth and Environmental Sciences. Amsterdam, The Netherlands.: Elsevier, 2019.

[20] A. Woods, "Using climate change projections in UK flood risk assessment," in Proceedings of the Institution of Civil Engineers: Water Management, 2015, vol. 68, no. 4, pp. 162-173, doi:10.1680/wama.13.00064.

[21] M. Darmawan and S. Theml, "Katalog Methodologi Penyusunan Peta Geo Hazard Dengan GIS." Aceh, Indonesia: BRR-NAD, 2008.

[22] E. Purnomo and H. Wahyono, "Measuring institutional collaboration on coping flood and rob in Panjang Baru Village Pekalongan City," in ICESI, 2019, pp. 1-10, DOI: 10.4108/eai.18-7-2019.2290118.

[23] Pemerintah Daerah Kabupaten Kendal, Rencana Tata Ruang Wilayah Kabupaten Kendal 2011-2031. 2020. 